\title{
The Mobility of Bakumpai Ethnics along Barito River in the Perspective of Trade and Spread of Islam (from $15^{\text {th }}$ to $19^{\text {th }}$ Century)
}

\author{
Yusliani Noor \\ History Education Department \\ Faculty of Teacher Training and Education \\ Universitas Lambung Mangkurat \\ Banjarmasin, Indonesia
}

\begin{abstract}
Bakumpai ethnic was the ethnic inhabiting the area of Muara Bahan which was located on the riverside of Barito River. Bakumpai ethnic was the first ethnic who embraces the arrival of Islam in the fifteenth century. Its geographically strategic position was the reason why Muara Bahan had become a trading post that was frequently visited by Muslim traders. The embracing of Islam from Bakumpai ethnic was indicated by the appearance of Raden Sira Panji Kesuma who accepted Islam along with the arrival of Sunan Giri and Sunan Bonang in Muara Bahan. The trading post of Muara Bahan as the center of Negara Daha had given an enormous impact towards the spreading of Islam in the trading post area and had also shaped the character of Bakumpai tribe both as the guardian and as the propagator of Islam. The dynamics of the Bakumpai ethnic's trading networks had expanded vastly to the other river flow areas such as Margasari River, Negara River, Amuntai River, and Tabalong River. The trading interactions in those estuaries had built good relationships between Bakumpai ethnic and several other ethnics such as Bukit ethnic, Maanyan ethnic, and Lawangan ethnic, including the Ngaju ethnic. The process of interactions, relationships, and trading networks had caused a consent and dissemination of Islam towards the other Dayak ethnics.
\end{abstract}

Keywords - mobility, Bakumpai, Islam religion

\section{INTRODUCTION}

Networking through the rivers in Kalimantan (Borneo) such as in Barito River had been found since the years of Negara Dipa Kingdom, Amuntai in the $12^{\text {th }}$ century. The Muara Rampiau and Muara Hulak trade ports had been visited by traders from various countries, such as China, Malay, Johor, Aceh, Melaka, Minangkabau, Patani, Mangkasar, Bugis, Bali, Java, Bentan, Palembang, Jambi, Tuban, Madura, Walanda, Makkau, as well as people from Keling [1][2]. However, as time and geomorphology changed, the trading activity in both trade ports was declined. Both were replaced by Muara Bahan trade port in Rantauan Bakumpai. The development of Muara Bahan grew along with the progress of Islamic trade in Nusantara or contemporary Indonesian term for the Indonesian archipelago in the $15^{\text {th }}$ century [3]. The movement of the trade center from Bandar Muara Rampiau to Muara Bahan exemplified how strategic Barito River was.
Throughout the commercial period of Hindu-Buddhist kingdom from the $8^{\text {th }}$ to $15^{\text {th }}$ century, Barito River and other rivers in the area of Hulu Sungai had been visited_by traders from outside South Kalimantan and Central Kalimantan. Based on the story of Hikayat Banjar or The Tale of Banjar, the trade port in Muara Bahan had been a busy trade port that had been visited by traders from various nations.

Due to the rapid progress of Islamic trade in the Indonesian archipelago, Muara Bahan had become an inseparable part of the shipping line of Muslim or people who embrace Islam traders from Java, Sumatera, Johor, Gujarat (India), and China. The rapid growth of the Muara Bahan cannot be separated from the interaction made by Bakumpai ethnic with Muslim traders who came from foreign lands. Even further, Bakumpai ethnic also traded with other ethnic communities, especially with Malay, Java, and Bugis. They also traded with other Dayak ethnics such as the Maanyan, Biaju (Ngaju), Bukit, and Lawangan ethnic. The attention of this paper is put on how the mobility of Bakumpai ethnic in Barito River affected other Dayak ethnics in accepting the arrival of Islam. Dayak ethnic, who had to hold Kaharingan belief with some embracing Hindu and Buddha, later hold Islam as their religion and became Dayak Islam.

The dynamic mobility of the Bakumpai community trade should thank to the bravery of the Bakumpai traders who rowed their deep down to the Hulu Sungai area. The growing intensity of other Dayak communities in welcoming the traders from Bakumpai had a big influence in the changing of belief in the other Dayak counterparts such as Dayak Maanyan, Bukit, and Lawangan. The most vivid change was marked by the emergence of settlements of Dayak Islam in almost every part of the riverbanks from Hulu Sungai to Tabalong Kiwa and Tabalong Kanan.

\section{METHOD}

This research used qualitative research methods to gain a deeply understanding of the Bakumpai Ethnic along Barito River. This qualitative research used deeply, long and open interviews for informant. Such a way, allowed researchers to 
provide broad opportunities for informants to express their views according to the perspectives they believe in.

\section{RESULT}

\section{A. Rantauan Bakumpai: The beginning of Islam in Central and South Kalimantan}

The Rantauan Bakumpai is a settlement that is located on the banks of Bahan River to the Kuripan area. The estuary of the Bahan River is directly connected to the Barito River. The city of Muara Bahan, now it is called as Marabahan, is located on the banks of Barito River. This place is very strategic as it connects Muara Banjar to Hulu Barito and Hulu Sungai area. The community inhibiting the Rantauan Bakumpai is Ngaju or Biaju. Moreover, according to the news from Ming Dynasty (1368-1643), book 323, it was explained that Be-oa-jiu was a major tribe in Dayak [4].

The most meritorious person in developing the trade port of Muara Bahan was the king of Negara Daha, Raden Sekar Sungsang. He appointed his son, Raden Sira Panji Kesuma as Syahbandar or harbour master in Muara Bahan. The description of Bakumpai was reported by Schwaner in his trip in Marabahan as part of a series of voyages along the Barito River between 1845 and 1847 [5].

Most Biaju or Ngaju people resided on the edges on the banks of major rivers. Among these, the Ngaju-Biaju ethnic lived near Kapuas River, Kahayan River, Barito River, and Bahan River. The support given by Muara Bahan community, who had been familiar with living on the banks of major rivers, played a great role in the development of the Muara Bahan. The development of Muara Bahan, that of Bakumpai ethnic and that of other Dayak ethnics were portrayed as a Kota Perahu or The City of Boats [5].

The dynamic life of the people in Muara Bahan in the $19^{\text {th }}$ century could explain the phenomenon of Muara Bahan trade port in the early $17^{\text {th }}$ century that had portrayed the interaction of its women with the Chinese trade ships. Based on the Chinese news of Dong Xi Yang Kao (1618), Book IV, vol.20, it was written that the women from the settlement used a small boat to get closer to the anchored ships to sell food. However, the trades, in general, were done by the men. Additionally, the currency used back then was the coin made of black lead [4]. The development of trading in Muara Bahan was also mentioned in Hikayat Banjar [1].

The Dayak Bakumpai was a community that was ready to accept changes, and this could be seen from how the community welcomed two Sunans or cleric who spread the teaching of Islam from Java, Sunan Giri and Sunan Bonang. The arrival of Sunan Giri to Muara Bahan was written in Riwayat Sunan Giri or The Tale of Sunan Giri [6] [7] [8]. The trades made by Sunan Giri or Raden Paku and Sunan Bonang or Makhdum Ibrahim in Muara Bahan were spread Islam. They spread the teaching of Islam by providing loans and goods from Java to the local traders, mostly from Dayak Biaju-Ngaju, who had financial problems. Thus, the community welcomed the Sunan Giri and Sunan Bonang to spread Islam in Muara Bahan.

\section{B. The Mobility of Bakumpai Traders and the Spread of Islam along the Barito River (Hulu Barito and Hulu Sungai)}

The pattern of river trading in the $16^{\text {th }}$ century, especially from the headstream community of Hulu Sungai and Hulu Barito with the traders of Muara Bahan trade port, was by barter trade. The traders brought along a variety of goods such as Javanese tamarind, salt, shrimp paste, rough textile, porcelain, and many more. The residents from the deep of Barito Rivers bought the goods by bartering them with other items such as gold, diamond, resin, honey, candle, rake wood, and gum. In fact, based on the news from Ming Dynasty (1368-1643 AD) mentioned that people of Baiju Ngaiju had much gold dust [4]. The exchange of goods with gold dust attracted the foreign traders to trade with the local traders.

In the middle of $16^{\text {th }}$ century, Khatib Banun, a figure from Bakumpai, appeared. He was the father in law of Sultan Hidayatullah who led the Banjarmasin Empire from 1570 to 1595. Khatib Banun, who was titled as Kyai or Leader of Islamic boarding school in Podok was assumed to be the member of a foreign merchant who had been given a chance to study the Qur'an in Pesantren Demak [9]. The title khatib in the name of this Bakumpai figure showed the importance of his position in the spreading of Islam along the Barito River. In fact, Khatib Banun was the religious advisor of Sultan Hidayatulah (1570-1595). Thus, he was an important figure in the spreading of Islam from Kuala Banjar to Hulu Barito and Hulu Sungai in the quarter of $16^{\text {th }}$ century.

Based on the local literature such as Hikayat Banjar, Tutur Candi, Hikayat Lembu Mangkurat, and Cerita Datu Bakumpai, the phenomenon of accepting Islam by Bakumpai community has been there since the $15^{\text {th }}$ century. They, then, took part in the network of Muslim traders of Bakumpai and spread Islam from the headstream of Barito River up to Dusun Hulu, continued from Muara Bahan, South Barito, to the banks of the Kapuas River, Dadahup, Katingan, to Buntok (Dusun) Pasar Lama, to the Penda Asam, Pendang, Muara Tewe, Muara Tuhup, and Tuhup [10].

The success of Islamization by the Bakumpai was fantastic at the end of the 19th century and the beginning of the 20th century. Helius Sjamsuddin mentioned that almost every year from the 1870s, Colonial of Verslag reported an increasing number of Dayak people who embraced Islam compared to evangelization by the Rheinische Missionsgesellschaft, that was deemed "underdeveloped" or "not much of a progress", or "unimportant" or "small" [5]. Weber believes that there was a historical fact of the role of Bakumpai community, Islam, and trades. He believes that among ideas, religious doctrines, and the imperative of material necessity does a meeting occur. They discover and strengthen each other [11].

One of the examples of trading done by a Bakumpai person came from a person named Wangkang. Wangkang, 1859, from Bakumpai, was a merchant who did his job in Barito, Tanah Dusun [12]. Based on Dutch sources, including the reports from Verspijck, the phenomenon explains that in the 19th century, an Islamic community was established. The powers of Dayak Islam influenced the struggle of Prince 
Antasari. This was an important point that explained the strong and long-lasting spread of Islam throughout the headstream of Barito River, including Puruk Cahu. The trade done by people of Dayak Bakumpai, who were still related with Dayak Biaju-Ngaju, became the undeniable power of history, notably in its role in Islamization along the Barito River, and the branching of its tributaries.

From Muara Bahan Bakumpai, the goods that had been commonly found in trade since the 14th and 15th centuries were increasingly easy to obtain. Along with the rising value of commodities of forest products and pepper plantations, people began to recognize the Chinese Pichin currency. As a result, the process of incoming goods from the upstream of the Barito River to the trade port of Bandar Masih was growing to be more dynamic. The similar phenomenon also occurred from Bandar Masih, Muara Bahan, Margasari, and Muara Hulak, in Batang Negara. These areas were inhabited by Maanyan community. The change in the religiosity of this region was marked by the presence of Islamic leaders such as Haji Sahabuddin and Haji Muhammad Taher, Negara. The Cerita Rakyat Daerah Kalimantan Selatan or The Folklore of South Kalimantan explained that there had been Islamic traders from Negara who underwent a Haj or Islamic Pilgrime done in Mecca in the early 18th century, namely Haji Sahabuddin and Haji Muhammad Taher [13].

Based on the Cerita Rakyat di Hulu Sungai Utara or Folklore in Hulu Sungai Utara, from the Negara area to Alabio and Banar River (Alabio) in South Amuntai, there were come a group from Demak led by Malik Ibrahim. Previously, Malik Ibrahim had built a mosque in Palajau through the Palayarum River in the 16th century [14][15]. From Amuntai to Batang Alai, Batang Balangan and Batang Tabalong, the activity in the port station of Murung Pudak had been shown by the Maanyan ethnic accepting basic commodities. In this trading network, through Batang Balangan to Batang Tabalong, they got supplies from Bakumpai traders at the mouth of the river. In Batang Balangan, early in the $17^{\text {th }}$ century, there had been a great Muslim scholar who was assumed coming from the ethnic of Bukit named Datu Kandang Haji. His real name was Surya Sakti Mangku Alam, and his Islamic name was Tuan Guru Haji Zainal Abidin [15].

According to Helius Syamsuddin, Bakumpai people played a major role in the Islamization of Banjarmasin (South Kalimantan, Central Kalimantan, and parts of East Kalimantan). They became intermediary traders between merchants from Banjar estuary who came to Muara Bahan's trade port and the merchants from the Hulu Barito and Hulu Sungai [5]. Islam in South Kalimantan formed the community of Banjar Pahuluan, Banjar Batang Banyu and Banjar Kuala [16].

\section{CONCLUSION}

Besides trading, Dayak people of Bakumpai participated in building villages on the edge along the Barito River. While spreading Islam, they mingled through marriage and friendship with other Dayak communities along the Barito River area. Dayak Bakumpai also helped build agriculture and plantation by, as the local community called, bahuma rice fields (building rice fields), looking for river fish, cutting wood, and other activities. They became an important part of building Islamic collectivity. They were very flexible in interacting with other Dayak tribes. This showed that Dayak Bakumpai really understood the religious tolerance. Therefore, Islam in South Kalimantan and Central Kalimantan is now very familiar with the Islamic concept of Rahmatan Lil 'alamin or Islam that is full of love for the universe as the Bakumpai traders introduced Islam with their idea of bilhikmah wabil-mauijatil hasanah or using wisdom and putting good ways above all.

\section{REFERENCES}

[1] J. J. Ras, Hikajat Bandjar, A Study in Malay Historiography, Leiden: The Hague Martinus Nijhoff, 1968.

[2] Tundjung, Kehidupan Ekonomi Negara Dipa dan Negara Daha, dalam Buletin Kayuh Baimbai, Meneropong Kembali Sejarah dan Kebudayaan Rakyat Banjar dari Zaman Pra Sejarah, Religi dan Kebudayaannya Hingga Perlawanan Rakyat Anti Kolonial, MSI (Masyarakat Sejarawan Indonesia) Cabang Banjar Kalimantan Selatan, No.1, Tahun 1 Februari 1991, Banjarmasin.

[3] M. C. Ricklefs, Sejarah Indonesia Modern, Yogyakarta: Gadja Mada University Press, 1993.

[4] W. P. Groeneveldt, Nusantara Dalam catatan Tionghoa, Jakarta: Komunitas Bambu, 2009

[5] H. Sjamsuddin, Pegustian dan Tumenggung, Akar Sosial, Politik, Etnis dan Dinasti, Perlawanan di Kalimantan Selatan dan Kalimantan Tengah 1859-1906, Jakarta: Balai Pustaka, 2001

[6] M. Syamsu As, Ulama Pembawa Islam di Indonesia dan Sekitarnya, Lentera Basritama, Jakarta,1999

[7] A. Kasdi, Kepurbakalaan (Sunan Giri di Indonesia dan Sekitarnya, Jakarta: Lentera, 1999,Sosok Akulturasi Kebudayaan Jawa Hindu dan Islam Pada Abad 15-16), IAIN Surabaya, 1987.

[8] R. Sofwan, Islamisasi di Jawa, Wali Songo, Penyebar Islam di Jawa Menurut Penelitian Babad, Yogyakarta: Pustaka Pelajar, 2004.

[9] H. Abar, Panembahan Muda Aling (Datu Muning) Sebuah Studi Kasus tentang Kekuasaan dalam Masyarakat Banjar, Rantau: Pemerintah Kabupaten Tapin Kalimantan Selatan, 2003.

[10] D. R. Wulan, Komunitas Bakumpai Di Buntok (Barito Selatan), Abad ke-15 Hingga Dasawarsa Abad Ke-21, Skripsi, Banjarmasin: Program Studi Pendidikan Sejarah Jurusan P.IPS FKIP UNLAM, 2008.

[11] T. Abdullah, Tesis Weber dan Islam di Indonesia, dalam Agama, Etos Kerja dan Perkembangan Ekonomi, Jakarta: LP3ES, 1979.

[12] H. Sjamsuddin, Wangkang Sang Hulu Balang, Martapura: Pustaka Agung Kesultanan Banjar, 2013.

[13] Y. Aziddin, Cerita Rakyat Daerah Kalimantan Selatan, Jakarta: Departemen Pendidikan dan Kebudayaan Proyek Inventarisasi dan Dokumentasi Kebudayaan Daerah, 1980/1981

[14] M. M. Elfa, Sejarah Mesjid Keramat Pelajau Barabai, Barabai: Badan Pengelola Mesjid Keramat, Barabai, 2002

[15] Y. Noor, Islamisasi Banjarmasin Dari Abad 15 Hingga Abad Ke-19, Yogyakarta: Komunitas Bambu, 2016.

[16] L. Potter, Banjarese and Beyond Hulu Sungai, South Kalimantan, dalam J. Thomas Lindblad, New Challenges in the Modern Economic History of Indonesia, eiden: Programme of Indonesian Studies, 1993. 